\title{
Profanity and Characterization: A Study of Translation Strategies and Their Effects on The Catcher in the Rye
}

\author{
Fachrina Azura, Haru Deliana Dewi, Rahayu Surtiati Hidayat \\ harudd.dewi7@gmail.com \\ Graduate of the English Study Program, Faculty of Humanities, Universitas Indonesia; \\ Department of Linguistics, Faculty of Humanities, Universitas Indonesia
}

\begin{abstract}
This paper investigates the translation strategies used in translating profanity in the novel The Catcher in the Rye and their effects on the narrator's characterization. The purpose is to see the effects that certain translation strategies have on characterization, an important literary element. This paper will focus on Chapter 25, the penultimate chapter where the climax takes place. This paper uses statistics to examine the number of translation strategies used and the qualitative-descriptive method to examine the effects on the narrator's characterization. The strategies will be classified based on Baker's (2018) proposed strategies, while Nida's (2012) argument regarding the importance of characterization will be the framework for evaluating the characterization. This paper finds that the Indonesian translator overwhelmingly used the strategies of softening and omission. This results in a significantly different characterization of the narrator, in which he becomes less irreverent and more conscious of social norms.
\end{abstract}

Keywords: characterization, literary translation, translation strategies, profanity

\section{Introduction}

The translation of vulgar and specifically profane language in literary text poses a question for translators: which translation strategy should they use in translating the profanity? This is a difficult question to answer since whichever strategy chosen will affect the text's literary quality. Unfortunately, few studies are conducted on this topic. As a novel that is notorious for its profane language, The Catcher in the Rye (henceforth Catcher), written by Jerome David Salinger (commonly known as J. D. Salinger), is a suitable corpus for such a study. An investigation of the strategies used in the English-Indonesian translation of Catcher will be useful for other translators, either Indonesian or others, in deciding the most appropriate approach for the process of translating Catcher or other books with excessive profanity in their prose. The result of this study can also be used as the groundwork for future researchers in examining the strategies of translating profanity in literary texts and how those strategies affect the quality of the text.

This study aims to investigate the translation strategies used in translating the profanity in Catcher and their effects on the characterization of the narrator. It will do so by asking two questions. First, what are the translation strategies used by the Indonesian translator in translating the profanity in Catcher? Second, does the choice of strategies affect the characterization of the narrator, and if yes, in what way?

This study will use the qualitativedescriptive method. First, this study will record all profanities found in Chapter 25 and their translation. Next, it will analyze the strategies used. Third, it will examine whether the same English word is translated consistently by using the same strategy or not. The frequency of how often a term is 
translated using which strategy will be presented as simple statistics in the form of percentage and a pie chart. Finally, it will investigate the effects of said strategies on the characterization of the narrator.

\section{Previous Research on Catcher}

Considering that Catcher's language is the major reason for its notoriety, a translator working on translating the novel needs to be careful in choosing the translation strategies applied. This is due to the fact that the excessive profanity in the narrator's speech is an essential part of his characterization; a clear insight into his state of mind and personality (Kaplan 1956; Costello 1959; Edwards 1983). As such, translating the profanity can pose a challenging task, especially when translated into a language whose cultural attitude toward profanity is different from English. A translator, after all, is not only "linguistic mediators, but also cultural mediators" (Aisyah 2013:59). In mediating between the source culture and the target culture, the translator will have to rely on a number of translation strategies. Whatever strategies the translator chooses, they will affect the quality of the prose, especially in regard to the characterization of the narrator.

Unfortunately, there are very few studies that focus on the issue of translation strategies of vulgar language found in Catcher and their effects on the text or the characterization. Heiserman and Miller, Jr. (1956), Barr (1957), and Costello (1959) argued that the main character (Holden)'s speech was both typical of teenagers of his time and at the same time individual enough to show the character's personality, as shown through the main character's idiosyncrasies of vocabulary and syntax. Riedel (1980) and Jasaitytė (2015) employed a similar paradigm in their studies. Despite examining two different translations and the 35-year gap between their studies, both Riedel and Jasaityte found similar results. The former examined the German translation of Catcher, and the latter the Lithuanian translation. Both studies found that in translating the everyday teenagers' language depicted in Catcher, the translators employed similar strategies, mainly omission and softening. This choice of strategies was caused by the translators' attempts to make the book more acceptable in their respective societies, i.e. German and Lithuanian societies. As a result, both Riedel and Jasaitytė argued that the translations failed to convey everyday teenagers' language, as the original English edition did. In Riedel's findings, moreover, the main character's personality underwent a significant change: from the irreverent young man in the English original (Kaplan 1956; Trowbridge, 1968) to a well-behaved uppermiddle class young man in the German version. However, both studies did not elucidate the criteria for their claim that their respective societies were more conservative than US culture. Riedel, additionally, did not provide adequate elaboration for his argument that the German version of the main character is radically different from the English one. This study will address this research gap by providing further support for the argument regarding the effects that the translation strategies employed have on Holden's characterization. This study will do so by using Nida's (2012) claim regarding the importance of maintaining the characterization in translating a literary text. However, this study will not discuss in depth the possible reasons behind the translator's decisions to employ certain strategies.

So far there has been no similar study conducted in Indonesian. The closest research on the topic of the translation of profanity is a study on the taboo words in the film 8 Mile, a 2002 drama/hip hop American movie about a young rapper, and their subtitle translation to Indonesian. Surya (2014) found that in translating such words, the translator chose to employ euphemism in order to make the subtitle more appropriate and less offensive for Indonesian audience. Thus, the motive for the translation strategy chosen is similar to Riedel's and Jasaityte's findings. However, it is important to note that there are significant differences between translating subtitles and novels. Besides the difference in length, subtitles also work together with other elements of the film, such as sounds and cinematography, which provide the audience with other cues for understanding the text. Indeed, this interaction between audio-visual elements and subtitle text renders complete translation of speech unnecessary, and in fact 
it should be avoided (Díaz Cintas and Remael 2014:145). In contrast, the readers of a novel fully depend on the words as their means of understanding the text. They rarely have illustrations or other elements to aid them. Translating novels, therefore, is significantly different from translating subtitles, and a study of subtitle translation might yield conclusions that may not apply to a study of literary texts translation. Due to this lack of studies regarding the translation of profanity in literary texts, a further investigation is needed.

\section{Theories on Profanity and Translation}

Hughes (2006:xvii) explains that, "When . . . sacred names, figures, or objects of veneration are invoked in an unsanctioned way, lightly and irreverently, and especially when they are used to swear at somebody or simply out of exasperation..." these instances can be referred to as profanity or blasphemy, among others. While profanity and blasphemy are quite similar, the main difference between them is on the intention, "in that profanity is usually regarded as habitual," while blasphemy "is more obviously intentional or deliberate" (Hughes 2006:xvii). Profanity, then, can be said as the usage of sacred words irreverently but without malicious intent. The function of profanity, as Hughes has stated above, is to show exasperation or to show annoyance at someone (2006). Being connected with religion, profanity is naturally culture-dependent. For example, a JudeoChristian culture will have different views on profanity compared to an Islamic one. Indeed, Islam is the only Abrahamic religion to explicitly prohibit profane or obscene words in its texts, while both the Old and New Testament are vaguer in this issue (Palmer 2012).

Levý argues that translating “. . . is a decision process," in that a translator is required to choose from a certain number of options (2000:148). In translating profanity, a translator has several options: to translate the profanity as it is, to maintain the expressive quality but not the profanity itself (softening), or to omit the profanity entirely (omission). What option the translator chooses will depend on both linguistic and non-linguistic considerations, such as whether the sentence will flow better or whether the audience will react well. Whatever options the translator chooses, they will affect the text, either positively or negatively.

\section{Baker's Translation Strategies}

Baker proposes that one of the strategies that a professional translator can use when dealing with non-equivalence is the strategy of translation by a more neutral or less expressive word (2018:27-30). As Baker herself does not give any name to this strategy, this paper will refer to this strategy using the term 'softening', a term used by Jasaitytè. She added that the purpose of this strategy was for "[T]he reduction of emotional harm and unpleasant effects of the word" (2015:17). As Butkuvienè and Petrulionè noted, rude or vulgar words are usually translated using this strategy (2010:40). However, choosing this strategy may result in a significant stylistic or expressive loss.

Omission, as Baker explains, can seem drastic, but in some instances omitting a word or expression is harmless, especially if the meaning is not particularly important. At the same time, she suggested that this strategy should only be used as a last resort, since some loss of meaning cannot be avoided when this strategy is employed (2018: 43-45). It should be noted that while a word or expression may be deemed to have relatively unimportant meaning, it may serve a stylistic purpose that is valuable to the text and whose absence may affect the text.

\section{The Link between Cursing and Personality}

To understand why someone curses, Jay argues that, "The answer ... must make reference to personality factors because an act of cursing is woven into a speaker's personality" (1999:107). Cursing reveals a speaker's personality, not only through his/her choice to curse but also from the words that s/he uses (Jay 1999:107). A person or character who uses excretory words to curse gives a different impression from one who uses profane words. Moreover, a person's personality factors can be used to predict 
his/her likelihood of cursing. Jay states that high emotionality or impulsivity, masculinity, and post-conventional morality, among other factors, are good indicators of a person's tendency to curse (1999:113-114).

Regarding profanity, Jay shares Hughes's distinction between profanity and blasphemy. He observes that "to be profane means to be secular or indifferent toward religion"; while to be blasphemous is to attack religion intentionally (1999:191). Furthermore, he elaborates that a person's involvement in a religious community shapes his/her attitude towards profanity and blasphemy. A person's religiosity, or depth-of-religious belief, is nurtured through conditioning in a religious community. Through censorship and education over "good" and "bad" language, a person learns the emotional meaning of profanity. The more involved someone is in a religious community, the higher his/her religiosity is. A person with high religiosity "tends to be offended by profanity" and therefore $\mathrm{s} /$ he is less likely to utter profanity (1999:108-109,190-192).

\section{Nida's Importance of Characterization}

Nida states that in translating literary works, "...each character must be permitted to have the same kind of individuality and personality as the author himself gave them in the original message" (2012:154). In other words, the characterization must remain visible in the target text. A character that is foul-mouthed, for example, must remain foulmouthed in the target text. The translator should not suddenly turn him/her into a polite person. He also emphasizes the importance of diction as a vital element of characterization. "Individuals must be properly characterized by the appropriate selection and arrangement of words," as Nida explains (2012:154). As such, the translator must keep intact the diction assigned to a character by the original author. This link between a character's diction and his/her personality echoes the arguments presented by Jay, as has been explained in the previous section.

\section{Scope of Research}

Despite being a critically acclaimed novel,
The Catcher in the Rye (first published by Little, Brown and Company in 1951) is also a perennial presence in American Library Association (ALA)'s list of frequently challenged book. The book's vulgar language, which includes excessive profanity in the narrator's speech, is the main reason cited for its banning from the school curriculum (Whitfield 1997; American Library Association 2013). This controversy surrounding the book may also be the reason why, despite being highly acclaimed, it was only in 2007 that the book was finally translated and published in Indonesia.

Catcher is the story, told from the first person point of view, of Holden Caulfield. While the setting is never explicitly stated, it can be inferred from information found in the text that the story takes place around late 1940 s or early 1950s. The novel begins with Holden directly addressing the readers from where he is staying, an institution implied to be one for tuberculosis patients. He then proceeds to recount the events of previous year's Christmas. A sixteen-year-old young man from an affluent family, he is expelled from his boarding school in Pennsylvania. This is the fourth time he has been expelled from a school. To avoid facing his parents' anger upon hearing the news, he returns to and then roams New York City for a few days. The novel consists of him telling the readers his observations regarding various people, events, and random things that he encounters. For the purpose of this study, the main focus will be on the main character, Holden, and his narration. His verbal interactions with people and the contexts of the speeches will also be taken into account.

The corpus for this study is the original English version of The Catcher in the Rye, written by Jerome David Salinger and first published in 1951 in the United States, and its Indonesian translation. The English language copy used for this study is the 1991 edition published by Little, Brown and Company. The Indonesian translation was published in 2007 by Banana and translated by Gita Widya Laksmini. Due to time and space limitation, this paper will focus only on Chapter 25 . The chapter was chosen because of its significance as the penultimate chapter where the climax 
takes place. However, when supporting information is needed, the paper will reference other chapters briefly.

\section{Translation Strategies Found in Catcher}

A close examination on Chapter 25 of the novel The Catcher in the Rye and its Indonesian translation reveals the following result:

Figure 1: Statistics of Translation Strategies Found in Chapter 25

Strategies Used in Translating Profanity in Chapter 25

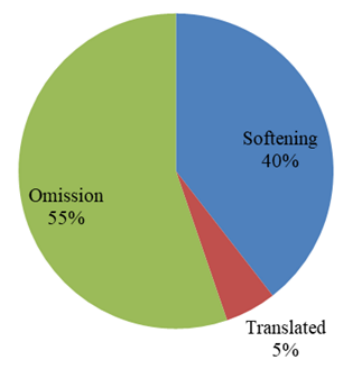

There are 38 words or expressions containing profanity in the source text. They consist of the words 'damn', 'goddam', and 'hell'. It is important to note that the author, Salinger, used the 'goddam' spelling instead of the more commonly used 'goddamn'. In the target text, however, the majority of them (55\% or 21 out of 38 ) have been translated using the strategy of omission. Forty per cent or 15 of these words/expressions are translated using the strategy of softening. Only $5 \%$ or 2 of them have their translation in the target language.

Of the two translated profane words, one involved the word 'damn' and the other 'goddam'. Both are translated using the same Indonesian word, 'sialan'. According to the online Kamus Besar Bahasa Indonesia [The Great Dictionary of the Indonesian Language] (henceforth KBBI), 'sialan' is a vulgar noun used for swearing. It is derived from the word 'sial', an adjective meaning unlucky (2016). Although the dictionary defines 'sialan' as a noun, in daily usage, the word is also used as an adjective. For example, a person who stumbles on a rock may say, "Batu sialan!" and when translated into English, the phrase becomes "Damned stone!" In this example, the word 'sialan' functions as an adjective to the noun 'batu'. While the word is considered vulgar, it is not profane in the sense that it is not based on religious expression. Despite this, the word can still be considered the equivalent of 'damn' and 'goddam' due to its vulgarity and terms of usage. The following is an examination of the two instances:

Table 1: Translated profane words

\begin{tabular}{|c|c|c|c|}
\hline Example & $\begin{array}{c}\text { Source } \\
\text { Text }\end{array}$ & $\begin{array}{c}\text { Target } \\
\text { Text }\end{array}$ & $\begin{array}{c}\text { Back } \\
\text { Translation }\end{array}$ \\
\hline (1) & $\begin{array}{l}\text { "But this } \\
\text { damn } \\
\text { article I } \\
\text { started } \\
\text { reading } \\
\text { made me } \\
\text { feel } \\
\text { almost } \\
\text { worse." } \\
(195)\end{array}$ & $\begin{array}{l}\text { "Tetapi } \\
\text { artikel } \\
\text { sialan } \\
\text { yang aku } \\
\text { baca ini } \\
\text { justru } \\
\text { membuat } \\
\text { aku } \\
\text { merasa } \\
\text { semakin } \\
\text { tidak } \\
\text { karuan." } \\
\text { (275) }\end{array}$ & $\begin{array}{l}\text { "But this } \\
\text { damn article } \\
\text { I'm reading } \\
\text { just makes } \\
\text { me feel more } \\
\text { messed up." }\end{array}$ \\
\hline (2) & $\begin{array}{l}\text { "You } \\
\text { can't } \\
\text { trust } \\
\text { anybody } \\
\text { in a } \\
\text { goddam } \\
\text { school." } \\
\text { (201) }\end{array}$ & $\begin{array}{l}\text { "Kita tak } \\
\text { bisa } \\
\text { percaya } \\
\text { pada } \\
\text { siapa pun } \\
\text { di sekolah } \\
\frac{\text { sialan ini." }}{(282)}\end{array}$ & $\begin{array}{l}\text { "We can't } \\
\text { trust anybody } \\
\text { in this } \\
\text { goddam } \\
\text { school." }\end{array}$ \\
\hline
\end{tabular}

In both instances, the profanity is retained, and so is its position. In example (1), the word 'damn' functions as the adjective of the word 'article' in the source text. In the target text, the word 'sialan' also functions as the adjective of the word 'artikel'. Likewise, in example (2), the words 'goddam' and 'sialan' function as the adjective of the words 'school' and 'sekolah' respectively.

The above instances are the only instances where the words 'damn' and 'goddam' are translated. There are seven uses of the word 'damn', yet only one is translated into its equivalent. Another is translated using the strategy of softening, while the other five instances are omitted in the translation. Following is an examination of a few examples of the word 'damn'. 
Table 2: Examples of the softening and omission of the word 'damn'

\begin{tabular}{|c|c|c|c|}
\hline Example & $\begin{array}{c}\text { Source } \\
\text { text }\end{array}$ & Target Text & $\begin{array}{c}\text { Back } \\
\text { Translation }\end{array}$ \\
\hline (3) & $\begin{array}{l}\text { “... it } \\
\text { damn } \\
\text { near } \\
\text { killed } \\
\text { me..." } \\
(212)\end{array}$ & $\begin{array}{l}\text { “... ini benar- } \\
\text { benar bikin } \\
\text { aku geli...” } \\
\text { (296) }\end{array}$ & $\begin{array}{l}\text { "It really } \\
\text { amused } \\
\text { me." }\end{array}$ \\
\hline (4) & $\begin{array}{l}\text { “... I } \\
\text { damn } \\
\text { near got } \\
\text { killed } \\
\text { doing } \\
\text { it..." } \\
(199)\end{array}$ & $\begin{array}{l}\text { “...aku } \\
\text { nyaris mati } \\
\text { ketabrak } \\
\text { mobil } \\
\text { karenanya...” } \\
(280)\end{array}$ & $\begin{array}{l}\text { "I almost got } \\
\text { killed by a } \\
\text { car because } \\
\text { of it." }\end{array}$ \\
\hline (5) & $\begin{array}{l}\text { "I felt so } \\
\text { damn } \\
\text { happy all } \\
\text { of a } \\
\text { sudden..." } \\
\text { (213) }\end{array}$ & $\begin{array}{l}\text { "Tiba-tiba } \\
\text { saja aku } \\
\text { merasa } \\
\text { begitu } \\
\text { bahagia..." } \\
\text { (297) }\end{array}$ & $\begin{array}{l}\text { "Suddenly I } \\
\text { felt so } \\
\text { happy." }\end{array}$ \\
\hline
\end{tabular}

In example (3), the strategy used is softening. The word 'damn' in the source text functions as an emphasis. In the target text, this function is taken by the phrase 'benarbenar'. The profanity is not retained, but the function is. The strategy of omission is used in examples (4) and (5). In the case of example (4), the function of the word 'damn' in this sentence is the same as the previous one, i.e. as emphasis, yet in this instance the word is omitted entirely from the target text. Similarly, in example (5), the word 'damn' again emphasizes how happy Holden was. However, the word is also omitted in the target text.

Based on the samples above, it seems that the word 'damn' was translated into its equivalent when the word functions as an adjective. In contrast, when the word functions as an emphasis, the translator either softened or omitted the word. There seems to be no discernible pattern on why certain 'damn(s)' have been softened and others have been omitted.

As with the word 'damn', only one 'goddam' was translated, even though the word appeared ten times. Two were softened, and the remaining seven were omitted.
Table 3: Examples of the softening and omission of the word 'goddam'

\begin{tabular}{|c|c|c|c|}
\hline Example & Source Text & $\begin{array}{c}\text { Target } \\
\text { Text } \\
\end{array}$ & $\begin{array}{c}\text { Back } \\
\text { Translation } \\
\end{array}$ \\
\hline (6) & $\begin{array}{l}\text { “... and she } \\
\text { was } \\
\text { dragging this } \\
\text { goddam big } \\
\text { suitcase with } \\
\text { her.” (205- } \\
\text { 206) }\end{array}$ & $\begin{array}{l}\text { “... dan ia } \\
\text { menyeret- } \\
\text { nyeret } \\
\text { satu kopor } \\
\text { yang besar } \\
\underline{\text { bukan }} \\
\underline{\text { main." }} \\
(288)\end{array}$ & $\begin{array}{l}\text { "...and she } \\
\text { was dragging } \\
\text { one enormous } \\
\text { suitcase." }\end{array}$ \\
\hline (7) & $\begin{array}{l}\text { “...and I } \\
\text { didn't even } \\
\text { have a } \\
\text { goddam } \\
\text { handkerchief } \\
\text { with me." } \\
(195)\end{array}$ & $\begin{array}{l}\text { "...dan aku } \\
\text { sama } \\
\text { sekali } \\
\text { tidak bawa } \\
\text { sapu } \\
\text { tangan." } \\
(274)\end{array}$ & $\begin{array}{l}\text { "...and I didn't } \\
\text { bring any } \\
\text { handkerchief." }\end{array}$ \\
\hline (8) & $\begin{array}{l}\text { "...and got } \\
\text { back on the } \\
\text { goddam } \\
\text { carrousel } \\
\text { just in time." } \\
(212)\end{array}$ & $\begin{array}{l}\text { “...dan } \\
\text { naik ke } \\
\text { atas } \\
\text { komidi } \\
\text { putar } \\
\text { tepat pada } \\
\text { waktunya." } \\
(297)\end{array}$ & $\begin{array}{l}\text { "...and got } \\
\text { back on the } \\
\text { carrousel just } \\
\text { in time." }\end{array}$ \\
\hline
\end{tabular}

In example (6), the strategy used is softening. The word 'goddam' in this sentence, as an adverb, emphasizes the size of the suitcase ('big'). In the target text, this function is taken up by the phrase 'bukan main', which is an adverb used to describe something that is extravagant (KBBI 2016). Examples (7) and (8), meanwhile, are translated using the strategy of omission. Both instances of the word 'goddam' act as the adjective for the nouns 'handkerchief' and 'carrousel' respectively. In the target text, however, the equivalents of those words ('sapu tangan' and 'komidi putar') are left without an adjective.

Based on the samples above, it seems that just like the word 'damn', there is no discernible pattern on the strategy chosen for translating the word 'goddam'. While the word generally has the same function, which is as an adjective that emphasizes the consequent nouns, the decision whether the word is translated into its equivalent, softened, or omitted seems to be entirely random.

Regarding the word 'hell' and its derivations, they appear for 21 times. However, not a single 'hell' was translated to its Indonesian equivalent, despite the availability of two possible equivalents for this 
word. The first is its literal translation, 'neraka'. The second is a loan word from Arabic, 'jahanam'. The online KBBI (2016) defines the word as an adjective, used in an informal discourse, meaning 'terkutuk' or 'cursed'. While 'neraka' would be a more direct translation, 'jahanam' is more commonly used as profanity. Indonesians almost never use 'neraka' to swear; they use 'jahanam' instead. Out of 21 instances of the word 'hell', twelve are softened and nine are omitted.

Table 4: Examples of softening

\begin{tabular}{|c|c|c|c|}
\hline Example & $\begin{array}{c}\text { Source } \\
\text { Text }\end{array}$ & $\begin{array}{c}\text { Target } \\
\text { Text }\end{array}$ & $\begin{array}{c}\text { Back } \\
\text { Translation }\end{array}$ \\
\hline (9) & $\begin{array}{l}\text { "Maybe he } \\
\text { was only } \\
\text { patting my } \\
\text { head just } \\
\text { for the hell } \\
\text { of it." (195) }\end{array}$ & $\begin{array}{l}\text { "Mungkin } \\
\text { ia hanya } \\
\text { menepuk- } \\
\text { nepuk } \\
\text { kepalaku } \\
\text { karena } \\
\text { iseng." } \\
(274)\end{array}$ & $\begin{array}{l}\text { "Maybe he } \\
\text { was only } \\
\text { patting my } \\
\text { head to } \\
\underline{\text { mess up }} \\
\text { with me." }\end{array}$ \\
\hline (10) & $\begin{array}{l}\text { "We had a } \\
\text { helluva } \\
\text { time." } \\
(197)\end{array}$ & $\begin{array}{l}\text { “Asyik } \\
\text { sekali saat } \\
\text { itu." (277) }\end{array}$ & $\begin{array}{l}\text { "It was very } \\
\text { fun at that } \\
\text { time." }\end{array}$ \\
\hline (11) & $\begin{array}{l}\text { "I'd be } \\
\text { casual as } \\
\text { hell." (205) }\end{array}$ & $\begin{array}{l}\text { "Aku akan } \\
\text { santai } \\
\text { sesantai- } \\
\text { santainya." } \\
(287)\end{array}$ & $\begin{array}{l}\text { "I'd be as } \\
\text { casual as } \\
\text { possible." }\end{array}$ \\
\hline (12) & $\begin{array}{l}\text { "What the } \\
\text { hell's in } \\
\text { that bag?" } \\
(206)\end{array}$ & $\begin{array}{l}\text { "Apa sih isi } \\
\text { kopor ini?" } \\
(288)\end{array}$ & $\begin{array}{l}\text { "What is in } \\
\text { this bag?" }\end{array}$ \\
\hline
\end{tabular}

In example (9), the function is retained, but the profanity is not. According to Dictionary.com, the phrase 'for the hell of something' means 'for the fun of something' (n.d.). It refers to that

act of doing something for mere enjoyment, not for meaningful or serious reasons. In the target text, the phrase is translated using the word 'iseng', which is an adjective with a similar meaning to the original English phrase. The word, however, is not profane and is a perfectly mundane one. Similarly, in example (20), the word 'helluva' is a pronunciation spelling of the phrase 'hell of a' and is used as intensifier (Dictionary.com n.d.). In this instance, the word functions as the intensifier of the word 'time', to describe how enjoyable the time was for the pronoun ' $\mathrm{We}$ ', which refers to Holden and Phoebe. In the target text, the word is translated into the phrase 'asyik sekali', with 'asyik' denoting the enjoyment and 'sekali' as the intensifier. The function of the word 'hell' in example (11) is slightly different. The word 'hell' in this sentence is used as an interjection, with the purpose of emphasizing how casual Holden wants to be. The target text instead uses a repetitive variant of the word 'santai' ('casual'), which is not profane. In Indonesian, a repetitive variant of a word can be used as an interjection in order to emphasize that word. Take for example the sentence, "Saat liburan tiba, aku bisa bebas sebebas-bebasnya." Translated literally to English, the sentence will become, "When holiday comes, I can be as free as freedom itself." To emphasize the speaker's desire for freedom, the word 'bebas' or 'free' is repeated twice with added prefix and suffix. The derivative word 'sebebas-bebasnya' then functions as an interjection to emphasize the root word 'bebas'. This of course does not conform to English syntactic rules. As with the previous example, the word 'hell' in example (12) is also an interjection, to emphasize Holden's insistence in knowing the bag's content. In the target text, the word used is 'sih', a particle used in conversation, especially in interrogative sentences, for added emphasis (KBBI 2016). The particle is untranslatable, so the closest English equivalent will be in a stronger intonation in the word 'is'.

Table 5: Examples of omission

\begin{tabular}{|c|c|c|c|}
\hline Example & $\begin{array}{c}\text { Source } \\
\text { Text }\end{array}$ & $\begin{array}{c}\text { Target } \\
\text { Text }\end{array}$ & $\begin{array}{c}\text { Back } \\
\text { Translation }\end{array}$ \\
\hline (13) & $\begin{array}{l}\text { "I got } \\
\text { excited as } \\
\text { hell } \\
\text { thinking } \\
\text { about it." } \\
\text { (p. 199) }\end{array}$ & $\begin{array}{l}\text { "Aku } \\
\text { langsung } \\
\text { merasa } \\
\text { bergairah } \\
\text { memikirkan } \\
\text { tentang hal } \\
\text { ini." (p. } \\
\text { 279) }\end{array}$ & $\begin{array}{l}\text { "I } \\
\text { immediately } \\
\text { felt excited } \\
\text { thinking } \\
\text { about this." }\end{array}$ \\
\hline (14) & $\begin{array}{l}\text { "What the } \\
\text { hellya got } \\
\text { in there?" } \\
\text { (p. 206) }\end{array}$ & $\begin{array}{l}\text { "Ada apa di } \\
\text { dalam } \\
\text { kopor ini?" } \\
\text { (p. 289) }\end{array}$ & $\begin{array}{l}\text { "What's in } \\
\text { this } \\
\text { suitcase?" }\end{array}$ \\
\hline (15) & $\begin{array}{l}\text { "...and I } \\
\text { couldn't } \\
\text { see where } \\
\text { the hell } \\
\text { she was." } \\
\text { (p. 209) }\end{array}$ & $\begin{array}{l}\text { “... dan aku } \\
\text { tidak bisa } \\
\text { lihat dia } \\
\text { ada di } \\
\text { mana." (p. } \\
\text { 292) }\end{array}$ & $\begin{array}{l}\text { "And I } \\
\text { couldn't see } \\
\text { where she } \\
\text { was." }\end{array}$ \\
\hline (16) & $\begin{array}{l}\text { "That } \\
\text { depressed } \\
\text { the hell } \\
\text { out of } \\
\text { me." (p. } \\
\text { 211) }\end{array}$ & $\begin{array}{l}\text { "Itu } \\
\text { membuatku } \\
\text { merasa } \\
\text { sedih." (p. } \\
295)\end{array}$ & $\begin{array}{l}\text { "It made me } \\
\text { feel sad." }\end{array}$ \\
\hline
\end{tabular}


In example (13), the word 'hell' emphasizes how excited Holden is. Unlike the third softening example, however, the emphasis is omitted from the translation. As a result, there is a different level of intensity of feeling between the source and target texts. Source-text Holden is very excited, while his target-text self is merely excited. While the sentence in example (14) is very similar to the last softening example, the word 'hell' is not translated. This results in another discrepancy of feelings between source and target texts. In the source text, Holden is angry, and his profanity shows it. In contrast, in the target text, Holden comes across as merely curious and maybe a little annoyed. The word 'hell' in example (15) is an interjection to show Holden's frustration and concern. $\mathrm{He}$ is walking in the opposite side of the street from his sister, and he worries whenever he cannot see her. In the target text, however, the profanity is not translated; therefore, making Holden looks less concerned. As with previous examples, in example (16), the word 'hell' is also used for emphasis, to show how much it depresses Holden. However, the word is again not translated.

The choice of either softening or omission for the word 'hell' seems due to the lack of equivalent in Indonesian for the word and due to the different syntactic construction between English and Indonesian, as seen in the first (9) and third (11) softening examples.

\section{The Effects of the Translation Strategies on Holden's Characterization}

The translator's decision to rely on either softening or omission in translating profanity has brought several consequences, primarily the loss of a key aspect of Holden's personality, as his profanity is one of his defining characteristics. Another substantial loss is the loss of urgency provided by the emphasis given by the words.

One of the reasons why Catcher is such a controversial novel is the vulgar language used by its main character (who is also the narrator), Holden, as has been discussed previously in the introduction. Holden's language, however, is not vulgar for vulgarity's sake. Instead, it serves as a clear insight into his personality. The importance of Holden's use of vulgar and slang language to his characterization has been noted by several studies. Of primary notability is Costello's (1959) study, which discussed in-depth the use of slang and vulgar language and how it supported Holden's characterization. His study is supported by Jay's research regarding cursing and its link to personality. As Jay states, "We do not just utter curse words; curse words are part of our identities" (1999:82). A person's usage of curse words is as much a part of his/her personality as is his/her extroversion or introversion.

As Holden's use of profane language is a key part of his personality, which reflects the 1950s teenage vernaculars (Costello 1959:172), the translator should translate the profanity carefully, as some strategies may result in the loss of characterization. As has been discussed above, in translating the profanity, the Indonesian translator overwhelmingly chose to either soften (40\%) or omit (55\%) the profanity. This, of course, resulted in a decidedly different character of Holden. Unlike blasphemy, profanity bears no malicious intent in its irreverent use of religious-based words or phrases. Profanity does not intend to mock religion; it merely takes religion lightly. In spite of this, profanity is still considered a part of vulgar language. A character who disposes these words freely, therefore, presents a different impression compared to a character who uses the same words sparingly. Holden, being a selfproclaimed atheist who nonetheless "like[s] Jesus" (Salinger 1991:99), certainly has no qualms in throwing around the words 'damn' and 'goddam'. As Costello has noted, Holden used these two words interchangeably to show emotional feelings, either favorable, unfavorable, or indifferent (1959:175). This use of profane language illustrates Holden's disinterest in, but not disrespect to, religion. In other words, Holden's tendency to be profane reflects his low religiosity, as Jay suggests (1999:109). Moreover, Holden's use of profane words reflects Jay's argument regarding the link between profanity and indoctrination to religious community. Jay argues that indoctrination into a religious community teaches children of the emotional meaning of 
profanity, and thus the upbringing shapes their attitude toward profanity (Jay 1999:190-192). Holden, whose parents belong to different religions and whose siblings are all atheists (Salinger 1991:100), is most likely never been indoctrinated into a religious community. Therefore, he never learns the emotional meaning and the taboo surrounding profanity, which leads to him using profane words freely.

The profanity also serves to illustrate Holden's general irreverence. As Costello noted, the author seemed to envision the book "more in terms of spoken speech than written speech" (1959:180). Notably, at the beginning and the end of the book, Holden directly addresses his readers, using the pronoun 'you' and giving them advice. Throughout the book, he too keeps talking to the readers in his asides. As Holden would never know who his readers may be, his casual use of profane language shows that he has no interest in being polite or present a certain image of himself. When one addresses an unknown audience, one generally tries to stay polite or to avoid being offensive. Allan and Burridge referred to this action as the effort to maintain or enhance a speaker's face or public self-image. They also noted that the general expectation is for a speaker to be polite (2006:33). Holden, on the other hand, makes no effort to either enhance his self-image or be polite. This indicates Holden's reluctance to conform to social norms, which is supported by his actions throughout the book. His irreverence and reluctance to conform carry over to his interaction with his sister. In this chapter, Holden arranges to meet his sister so that he can return the money he has borrowed before he leaves town. Phoebe, his sister, shows up late, unexpectedly carrying a large suitcase. Holden, who has been worried, immediately asks her what is in the suitcase and insists that he does not need anything. Holden's exact words are, "What the hell's in that bag? ... What the hellya got in there?" (Salinger 1991: 206). Holden's use of the word is remarkable considering that his sister is only ten years old. He does not even attempt to use a more acceptable or child-appropriate variant of the word, 'heck'. This encounter marks the second time Holden interacts with Phoebe in the novel. Their first interaction, in the previous chapter, shows Holden behaving the same.
Phoebe's unfazed reaction to the profanity serves to show how normal this behavior is for Holden.

When compared to Holden in the target text, a stark difference of character becomes clear. Target-text Holden swears only twice in the whole chapter, a far cry from his source text self who swears 38 times. The impression given by the target text, with its decision to rely on softening and omission, is one of a relatively more restrained young man. The questions Holden asks his sister become more childappropriate, free from profanity. These losses of profanity have resulted in a Holden who is more respectful to religion, at least to Indonesian standard, and who is less irreverent to social norms. Target-text Holden addresses his readers relatively more politely and behaves himself in front of his little sister. He is less likely to offend his readers. These are the benefits of the translator's decision to rely on softening and omission.

However, the negative effects overshadow the positive ones. While it can be argued that this sets a better example of behavior in dealing with children, the profanity-free questions lack the easy camaraderie and strong bond between siblings that the original questions imply. Moreover, the use of 'damn' and 'goddam' to show emotional feelings (Costello 1959:175) is lost, resulting in a significant loss of clues for Holden's feelings regarding various things, events, or people. Holden's delineation, which Riedel stated "is characterized mainly through his language" (1980:198), is less apparent in the target text. The loss of his signature profane language has cost target-text Holden his delineation, which is shown through his irreverence towards religion, social norms, and polite behavior or face-saving. In a similar vein, Kaplan argued that the author's use of frequently vulgar language contributed greatly to the clarity of the character's personality, and that the language is "personal, distinctive, and descriptive of character" (1956:77). The loss of profanity, therefore, is always followed by the loss of Holden's distinctive characterization. By taking away the profanity, the translator has taken away the quality that makes Holden himself. 
Referring back to Nida, target-text Holden, then, due to the loss of profanity, is no longer "properly characterized" (2012:154). The "appropriate selection and arrangement of words" (ibid.) Salinger assigned carefully to Holden is lost. He no longer has "the same kind of individuality and personality as the author himself gave [him]" (ibid.). Therefore, the translator's choice to mainly omit or soften the profanity has negatively affected Holden's characterization, resulting in a different character from what the author, Salinger, intended him to be.

\section{Conclusion}

An examination of the translation strategies used in translating the profanity in the $25^{\text {th }}$ chapter of The Catcher in the Rye revealed that the Indonesian translator overwhelmingly relied on the strategies of omission and softening, with only two out of 38 instances of profanity were translated into their equivalent. There seems to be no discernible patterns regarding the reasons why certain 'damn' and 'goddam' were translated, softened, or omitted. As for the word 'hell', which was never translated into its equivalent, the choice to either soften or omit the word seemed to be based on syntactic and semantic considerations.

This overwhelming reliance on the strategies of softening and omission resulted in a drastically different characterization of the main character and narrator, Holden Caulfield. His narration and speech become more restrained and lack the emotional expressivity found in the source text. Holden changes from the irreverent young man in the source text to a more socially conforming one in the target text. This finding echoes those of previous studies, especially from studies regarding the German (Riedel 1980) and Lithuanian (Jasaitytè 2015) translations of Catcher. While it can be argued that softening and omission bring positive effects to the text, such as making the text less offensive to its readers, the negative effects to Holden's characterization outweigh the positive ones.

However, due to time and space limitation, the scope of this study was only the profanity in one chapter. Thus, the findings are quite insufficient to draw a well-founded conclusion regarding the translation strategies used and their effects on Holden's characterization. Further studies regarding the translation strategies used in translating profanity as well as other types of vulgar language in the whole novel and its translation will be necessary in order to draw a definite conclusion. Such studies will bring a new perspective in the issue of vulgar language translation, especially in relation to literary text translation. It will also bring practical benefits for other translators in determining the most appropriate approach in translating profanity and/or other vulgar language without compromising important elements of the prose, such as characterization.

The author of this study recommends further research to be conducted regarding translation strategies and their use in translating profane and vulgar language, especially in literary translation. Examinations of other literary works with significant vulgar language in them, how said language is translated, and the effects of the strategies employed in translating such a language will contribute greatly to the practical application of translating and by extension the quality of the translated versions.

\section{References}

Aisyah, Halida (2013) 'Cultural Understanding in the Indonesian Translation of The BabySitters Club', Paradigma, 4(1): 59-71.

Alan, Keith and Kate Burridge (2006) Forbidden Words: Taboo and the Censoring of Languages, Cambridge: Cambridge University Press.

American Library Association (2013) Banned \& Challenged Classics. Available online at [http://www.ala.org/advocacy/bbooks/f requentlychallengedbooks/classics] (accessed 5 November 2017) 
Baker, Mona (2018) In Other Words: A Coursebook on Translation (third ed.), London: Routledge.

Surya, Sang Putu Bangbang (2014) 'Taboo Words in the 8 Mile Movie and Their Translation into Indonesian', Humanis. Available online at [https://ojs.unud.ac.id/index.php/sastra /article/view/8855] (accessed 7 October 2017)

Barr, Donald (1957, October 25) 'Saints, Pilgrim \& Artists', Commonweal.

bukan main. (2016). Kamus Besar Bahasa Indonesia daring [The Online Great Dictionary of the Indonesian Language]. Available online at [https://kbbi.kemdikbud.go.id/entri/buk an\%20main] (accessed 29 November 2017)

Butkuvienè, Karolina and Lolita Petrulionè (2010) 'Translation Peculiarities of Slanguage', Studies About Languages, (16): 39-43.

Costello, Donald P (1959) 'The Language of The Catcher in the Rye', American Speech, 34(3): 172-181.

Díaz Cintas, Jorge and Aline Remael (2007) Audiovisual Translation: Subtitling, Oxon: Routledge.

Edwards, Duane (1997) 'Holden Caulfield: "Don't Ever Tell Anybody Anything"', ELH, 44(3): 554-565.

for the hell of it. (n.d.). Dictionary.com unabridged. Available online at [http://www.dictionary.com/browse/for --the--hell--of-it] (accessed 29 November 2017)

Heiserman, Arthur and James E. Miller, Junior (1956) ' J. D. Salinger: Some Crazy Cliff', Western Humanities Review, X(2): 129137.

helluva. (n.d.). Dictionary.com unabridged. Available online at [http://www.dictionary.com/browse/hel luva?s=t] (accessed 29 November 2017)

Hughes, Geoffrey (2006) An Encyclopedia of Swearing: The Social History of Oaths, Profanity, Foul Language and Ethnic Slurs in the English-speaking World, New York: M. E. Sharpe.

jahanam. (2016). Kamus besar Bahasa Indonesia daring [The Online Great Dictionary of the Indonesian Language]. Available online at

[https://kbbi.kemdikbud.go.id/entri/jaha nam] (accessed 29 November 2017)

Jasaitytè, Lina (2015) Swear Words in Teen Fiction and Their Translation from English to Lithuanian (Bachelor thesis). Available online at [http://talpykla.elaba.lt/elabafedora/objects/elaba:8712498/datastrea ms/MAIN/content] (accessed 28 May 2017)

Jay, Timothy (1999) Why We Curse: A NeuroPsycho-Social Theory of Speech, Amsterdam: John Benjamins Publishing Co.

Kaplan, Charles (1956) 'Holden and Huck: The Odysseys of Youth', College English, 18(2): 76-80.

Levý, Jiří (2000) 'Translation as a Decision Process', in Lawrence. Venuti (ed.), The Translation Studies Reader (first ed.), London: Routledge, 148-159.

Nida, Eugene (2012) 'Principles of Correspondence', in Lawrence Venuti (ed.), The Translation Studies Reader (third ed.), Oxon: Routledge, 141-155.

Palmer, B (2012, August 20) 'Thou Shalt not Have a Potty Mouth. Slate. Available online at

[http://www.slate.com] (accessed 1 June 2018)

Riedel, Walter E (1980) 'Some German Ripples of Holden Caulfield's 'Goddam Autobiography': On Translating and Adapting J. D. Salinger's The Catcher in the Rye', Canadian Review of Comparative Literature: 196-205. 
Salinger, Jerome David (1991) The Catcher in the Rye, New York: Little, Brown and Company.

Salinger, Jerome David (1991) The Catcher in the Rye, New York: Little, Brown and Company; trans. by Gita Widya Laksmini (2007) as The Catcher in the Rye, Jakarta: Banana.

sialan. (2016). Kamus besar Bahasa Indonesia daring [The Online Great Dictionary of the Indonesian Language]. Available online at [https://kbbi.kemdikbud.go.id/entri/sial an] (accessed 29 November 2017)

sih. (2016). Kamus besar Bahasa Indonesia daring [The Online Great Dictionary of the Indonesian Language]. Available online at [https://kbbi.kemdikbud.go.id/entri/sih] (accessed 29 November 2017)

Trowbridge, Clinton W (1968) 'Hamlet and Holden', The English Journal, 57(1): 26-29.

Whitfield, Stephen J (1997) 'Cherished and Cursed: Toward a Social History of The Catcher in the Rye, The New England Quarterly, 70(4): 567-600. 